\title{
Experience and professional training in the School Health Program
}

\author{
Experiência e capacitação profissional na execução do Programa Saúde na Escola \\ Experiencia y capacitación profesional en la ejecución del Programa Salud en la Escuela
}

Eliabe Rodrigues de Medeiros ${ }^{1}$, Erika Simone Galvão Pinto ${ }^{1}$

How to cite this article:

Medeiros ER, Pinto ESG. Experience and professional training in the School Health Program. Rev Esc Enferm USP. 2018;52:e03378. DOI: http://dx.doi. org/10.1590/S1980-220X2017048603378

${ }^{1}$ Universidade Federal do Rio Grande do Norte, Centro de Ciências da Saúde, Programa de Pósgraduação em Enfermagem, Natal, RN, Brazil.

\section{ABSTRACT}

Objective: To analyze the association between experience and professional training in the School Health Program. Method: Descriptive, inferential, quantitative and normative study. The data were collected from May to July 2017 through a questionnaire based in the School Health Program, with the participation of professionals from the Family Health Strategy. Results: 105 professionals participated in the study. The average time working in the Family Health Strategy and in the School Health Program is 12.1 and 7.2 years, respectively. $94.3 \%$ of the professionals feel qualified to perform the activities of the School Health Program, although only $30.5 \%$ have participated in training. There is statistical association between experience and professional training. Conclusion: The professionals who conduct activities in the School Health Program undergo few training processes, but feel qualified to carry out the activities proposed.

\section{DESCRIPTORS}

School Health Services; Primary Health Care; Primary Care Nursing; Professional Training.
Corresponding author:

Eliabe Rodrigues de Medeiros

Programa de Pós-graduação em Enfermagem,

Centro de Ciências da Saúde, Universidade

Federal do Rio Grande do Norte. Campus

Universitário, s/n, Lagoa Nova

CEP 59078-970 - Natal, RN, Brazil

eliabe.medeiros@hotmail.com 


\section{INTRODUCTION}

The School Health Program (Programa Saúde na Escola) is an intersectoral public policy under the responsibility of health and education sectors. It was created in 2007 with the purpose of contributing to the comprehensive education of public school students through actions of health promotion, disease prevention and health care ${ }^{(1)}$.

The actions implemented are organized into three components: assessment of health conditions (component I), health promotion and prevention of diseases (component II) and training of professionals and continuing education (component III) $)^{(2)}$.

In the first component, the activities proposed are related to vaccination status, anthropometric assessment and evaluation of oral health. The second component proposes activities that promote a culture of peace, environmental health education, sexual and reproductive health and prevention of Sexually Transmitted Diseases and AIDS (STD/AIDS). As for the third component, it is expected that trainings are carried out to support the participation of professionals in the implementation of the activities of components I and $\mathrm{II}^{(2-3)}$.

The proposition of this last component is that the professionals comprehend the organization of the School Health Program, receive training and participate in the actions carried out, contributing to the effectiveness of the program. These actions enable a connection between the professionals involved through permanent dialogues aimed at finding strategies to perform the project ${ }^{(4)}$.

However, it should be emphasized that the training and the experience of these professionals must be articulated and adapted to the context and the specific situations in which the interventions are carried out ${ }^{(5)}$. Thus, the experience of professionals in the Family Health Strategy (FHS) is an important factor for the implementation of the School Health Program.

For the implementation of the actions of the School Health Program, it is necessary to consider its intersectoral aspect as an important element for the integration between health care professionals and educators, who must collaborate in the process of articulation, planning and cooperation between sectors ${ }^{(6)}$. These aspects are reinforced by the need to consider health issues as interdisciplinary, which provides a broad view of the health-disease process and resoluteness in the care process ${ }^{(7)}$.

Given the above, we ask: Is the training provided to the professionals who carry out the activities of the School Health Program related to their professional experiences?

The answers to this question may contribute to the improvement of practices carried out by health professionals in the School Health Program, through training programs that meet the needs found. This becomes possible after understanding the association between training activities and experience of FHS professionals in the School Health Program, which is a gap that the present study intends to fill with the objective of encouraging the implementation and improvement of the activities proposed in component III.

Therefore, the objective was to analyze the association between experience and training in the implementation of the School Health Program.

\section{METHOD}

TYPE OF STUDY

Descriptive and inferential study, with quantitative approach and normative interpretation, which is characterized by the comparison between what is predicted in the normalization with what is identified in the professional practice $^{(8)}$.

\section{SCENARIO}

The research was carried out in the city of Natal, capital of the state of Rio Grande do Norte, where health services are organized in five districts (South, East, West, North I and North II), which have FHS offered by 38 Family Health Units (FHU). These are characterized by attention to primary health care planned according geographic localization of users.

\section{SELECTION CRITERIA}

In each one of the $38 \mathrm{FHUs}$, a professional from each professional category was selected to compose the population, totaling 228 professionals. The sample size calculation for a finite population, with a 5\% sampling error and a $95 \%$ confidence interval, defined that 144 professionals from the FHS of 24 FHUs would participate in the study, at least one of each professional category, namely: physician, nurse, nursing technician or assistant, community health agent, dentist and dental technician or assistant. The inclusion criteria were: having performed or be currently carrying out health activities in the school, in this case, activities proposed in components I and II.

\section{DATA COLLECTION}

Data collection was conducted by the researchers in the FHUs from May to July 2017, using a questionnaire based on the norms of the School Health Program. The questionnaire consisted of closed and open questions, divided into three parts: professional characterization, structure dimension and process dimension. For this research, closed questions were used for the process dimension. The adequacy of the questions in this instrument was verified by five professionals who work at the FHS.

\section{DATA ANALYSIS AND TREATMENT}

The data were organized and analyzed in the IBM SPSS Statistics, version 22.0, through descriptive statistics. The results were presented in absolute and relative frequency, mean, standard deviation and confidence interval, and in inferential statistics through the Fisher's, Chi-square and Student's-t tests, with the significance level of $5 \%$.

\section{ETHICAL ASPECTS}

Since it was a research involving human beings, it was presented to the Research Ethics Committee of the Universidade Federal do Rio Grande do Norte for appreciation, which analyzed its adequacy to Resolution 
466/2012, of the National Health Council. In May 2017 a favorable opinion was issued under protocol 2.064.901 and Certificate of Presentation for Ethical Consideration 64873916.1.0000.5537. Participants were informed about the possible risks of participating in the study and signed the Informed Consent Form.

\section{RESULTS}

Among the 144 professionals included in the sample, 39 did not participate in the study: 28 did not perform health activities at school, seven refused to participate and four were absent from professional activities during the data collection period.

Therefore, a total of 105 professionals participated in the study, of which six (5.7\%) were physicians, 20 (19.0\%) were nurses, 13 (12.4\%) were nursing assistants or technicians, $24(22.9 \%)$ were community health agents, 22 (21.0\%) were dentists and 20 (19.0\%) were dental technicians or assistants. Among these, females (84.8\%) were more predominant than males $(15.2 \%)$, and their distribution by health district was proportional to the number of FHUs, so $4.8 \%$ were from the South District, $15.2 \%$ from the East District, 25.7\% from the West District, 28.6\% from the North District I and 25.7\% from the North District II.

Regarding the qualification of the professionals, 17 (16.2\%) reported they had finished high school, 33 (31.4\%) had vocational training, 20 (19.0\%) had undergraduate course, 28 (26.7\%) were specialists, five (4.8\%) had a master's degree and two (1.9\%) had a PhD.

The characterization of the variables related to the experience of the professionals who work in the Health School Program is presented in Table 1.

It was observed that $90(85.7 \%)$ participants did not know how long they had been carrying out activities in the School Health Program. The mean participation time was 7.2 years.
Table 1 - Characterization of variables related to professional experience (in years) - Natal, RN, Brazil, 2017.

\begin{tabular}{lccc}
\hline Variables & Frequency & Mean & $\begin{array}{c}\text { Standard } \\
\text { deviation }\end{array}$ \\
\hline Age & 105 & 48.3 & 9.1 \\
Time in the profession & 105 & 22.3 & 9.6 \\
Time in the FHS & 105 & 12.1 & 5.1 \\
$\begin{array}{l}\text { Time in the School Health } \\
\text { Program }\end{array}$ & 90 & 7.2 & 5.3 \\
\hline
\end{tabular}

Table 2 presents the characterization of the variables used to describe the training of health professionals who participate in the School Health Program.

Table 2 - Characterization of variables related to professional training in the School Health Program - Natal, RN, Brazil, 2017.

\begin{tabular}{lcc}
\hline Variable & $\mathrm{N}$ & $\%$ \\
\hline Do you feel qualified? & & \\
Yes & 99 & 94.3 \\
No & 6 & 5.7 \\
Total & 105 & 100.0 \\
\hline Did you participate in training? & & \\
Yes & 32 & 30.5 \\
No & 73 & 69.5 \\
Total & 105 & 100.0 \\
\hline
\end{tabular}

A large part (94.3\%) of the professionals feel qualified to perform the activities of the School Health Program, but a smaller number (30.5\%) reported they had participated in training. The professionals mentioned that these training programs are generally under the responsibility of the program management (25.7\%), and are offered by the health and education offices, or are carried out by other institutions (4.7\%), such as partner higher education institutions.

These variables were statistically tested with the professional categories, and their results are showed in Table 3.

Table 3 - Characterization of the association between the variables referring to professional category and to professional training for the School Health Program - Natal, RN, Brazil, 2017.

\begin{tabular}{|c|c|c|c|c|c|c|}
\hline \multirow[b]{2}{*}{ Professional category } & \multicolumn{2}{|c|}{ Do you feel qualified? } & \multirow[b]{2}{*}{ P-value* } & \multicolumn{2}{|c|}{ Did you participate in training? } & \multirow[b]{2}{*}{ P-value* } \\
\hline & $\begin{array}{c}\text { Yes } \\
N(\%)\end{array}$ & $\begin{array}{c}\text { No } \\
\text { N (\%) }\end{array}$ & & $\begin{array}{c}\text { Yes } \\
\text { N (\%) }\end{array}$ & $\begin{array}{c}\text { No } \\
\text { N }(\%)\end{array}$ & \\
\hline Physician & $6(6.1)$ & - & & $1(3.1)$ & $6(5.7)$ & \\
\hline Nurse & $19(19.2)$ & $1(16.7)$ & & $8(25.0)$ & $12(16.4)$ & \\
\hline Nursing assistant or technician & $12(12.1)$ & $1(16.7)$ & & $4(12.5)$ & $9(12.3)$ & \\
\hline Community health agent & $21(21.2)$ & $3(50.0)$ & 0.636 & $6(18.8)$ & $18(24.7)$ & 0.136 \\
\hline Dentist & $22(22.2)$ & - & & $3(9.4)$ & $19(26.0)$ & \\
\hline Dental assistant or technician & $19(19.2)$ & $1(16.7)$ & & $10(31.3)$ & $10(13.7)$ & \\
\hline Total & $99(94.3)$ & $6(5.7)$ & & $32(30.5)$ & $73(69.5)$ & \\
\hline
\end{tabular}

Legend: *Fisher's and Chi-square test.

From the results presented, there is no evidence that there is a statistical association between professional category and professional training in the School Health Program.
Table 4 presents the results of the statistical association between feeling qualified to act in the program and the variables related to professional experience. 
Table 4 - Characterization of the association between feeling qualified and the variables related to professional experience - Natal, RN, Brazil, 2017.

\begin{tabular}{|c|c|c|c|c|c|c|}
\hline Variables & $\begin{array}{l}\text { Do you feel } \\
\text { qualified? }\end{array}$ & $N(\%)$ & $\mathbf{M}$ & SD & CI [L low; L upp] & P-value* \\
\hline \multirow{2}{*}{ Age } & Yes & $99(94.3)$ & 48.1 & 9.3 & \multirow{2}{*}[-10.5;4.7]{} & \multirow{2}{*}{$0.454^{* *}$} \\
\hline & No & $6(5.7)$ & 51.0 & 5.1 & & \\
\hline \multirow{2}{*}{ Time in the profession } & Yes & $99(94.3)$ & 22.4 & 9.8 & \multirow{2}{*}[-7.2;8.9]{} & \multirow{2}{*}{$0.827^{* *}$} \\
\hline & No & $6(5.7)$ & 21.5 & 8.0 & & \\
\hline \multirow{2}{*}{ Time in the FHS } & Yes & $99(94.3)$ & 12.0 & 5.3 & \multirow{2}{*}[-4.2;-0.1]{} & \multirow{2}{*}{$0.039 * * *$} \\
\hline & No & $6(5.7)$ & 14.2 & 1.8 & & \\
\hline \multirow{2}{*}{$\begin{array}{l}\text { Time in the School Health } \\
\text { Program }\end{array}$} & Yes & $85(94.4)$ & 6.9 & 5.3 & \multirow{2}{*}[-9.0;-0.7]{} & \multirow{2}{*}{$0.028^{* * *}$} \\
\hline & No & $5(5.6)$ & 11.8 & 3.4 & & \\
\hline
\end{tabular}

Legend: M: mean; SD: standard deviation; CI: Confidence Interval; *Student's t-test; ${ }^{* *}$ assuming equal variances; ${ }^{* * *}$ assuming unequal variances.

There is statistical association between feeling qualified and time working in the FHS and in the School Health Program.

\section{DISCUSSION}

The analysis allowed to identify that, despite the high number of professional categories that require secondary and vocational education, there was a greater number of professionals with undergraduate and graduate degrees. This may be related to the Continuing Education strategy, which proposes the availability of postgraduate education to professionals working at the FHS in order to meet the needs of health services ${ }^{(9)}$.

The time these professionals have been working in their areas presented an average of more than 20 years. In addition, this variable presented the highest standard deviation in relation to the others, which unveils the long time passed since the last civil service examination in the city of Natal and the hiring of temporary professionals to work in the FHS.

The mean time the professionals have worked in the FHS and in the School Health Program is shorter than their experience in the profession, however, this confirms the time of existence of the FHS and the School Health Program. The latter, for example, had approximately one decade of existence when the present research was carried out.

The variables related to professional training revealed that less than half of the professionals had participated in training activities. In contrast, most of them reported they felt qualified to carry out activities in the program. This aspect is possible considering that, even though training activities are not constant, professionals can seek knowledge from other sources, beyond the program, in order to meet their needs ${ }^{(10)}$.

The lack of training is not an exclusive finding of the present study. A study conducted in the state of Pernambuco also detected the deficiency of continuing education actions $^{(11)}$. The results showed the dissatisfaction of professionals with having participated in only one training in the 5 -year period, which was conducted when the program was implemented. The training provided was insufficient for professionals to obtain adequate qualification for the themes that would be performed in the context of the research ${ }^{(11)}$.
Dissatisfaction and inability may also be felt by the professionals of the present study. However, it is important to reaffirm that the training of these professionals is essential for the improvement and the quality of health care services provided to students.

The results also showed no statistical association between the professional category and the variable feeling qualified. However, it should be noted that the participation of the multi-professional team is necessary in the School Health Program, since, despite the possibility of participating in the same training activities, each of these professionals has their own specificities that can contribute to a broad view on school health actions ${ }^{(12)}$.

The statistical association between feeling qualified and time working in the FHS and in the School Health Program is similar to the findings of a study conducted in the state of Espírito Santo ${ }^{(13)}$. The authors found an association between attributes that include family and community orientation (which is possible when the team feels qualified to deal with community health problems) and the level of education and previous experience in the FHS. This reinforces the need to invest in training professionals and qualifying the care provided in these services, which include school health care ${ }^{(13)}$.

Therefore, it is essential to improve the training and continuing education of professionals working in the School Health Program, as it already occurs in other interventions aimed at the health of students in the United Kingdom ${ }^{(14)}$ and Canada ${ }^{(15)}$. These studies on healthy eating include the training of teachers and health professionals involved in the interventions as a proposal for their implementation.

This need to improve the abilities of the professionals is important, since in different scenarios, the actions of component I have been prioritized over component II, with actions centered on biology aspects and lectures ${ }^{(11,16)}$. Thus, the professional experience must be included in these trainings, supporting interprofessional exchange and consequently, the implementation of an intersectoral proposal, since the planning up to performing activities.

\section{CONCLUSION}

This study found that the professionals who conduct the activities of the School Health Program undergo few 
training processes, but feel qualified to carry out the activities proposed.

It was verified that, regardless of their role in the multiprofessional team, training and professional experience must be included in the execution of the actions of the program in order to achieve its effectiveness. This way, it is necessary to improve the activities of Component III - training of professionals and permanent education in the School Health Program - and to encourage its permanent and continuous performance with health and education professionals.

Other studies should be carried out to test the findings among education professionals, since they are professionals of equal importance in the implementation of the School Health Program.

\section{RESUMO}

Objetivo: Analisar a associação entre experiência e capacitação profissional na execução do Programa Saúde na Escola. Método: Estudo descritivo, inferencial, quantitativo e normativo. Os dados foram coletados no período de maio a julho de 2017 por meio de questionário construído a partir das normatizações do Programa Saúde na Escola, com a participação de profissionais da Estratégia Saúde da Família. Resultados: Participaram do estudo de 105 profissionais. A média de experiência profissional na Estratégia Saúde da Família e no Programa Saúde na Escola é de 12,1 e 7,2 anos, respectivamente. Identificou-se que 94,3\% dos profissionais sentem-se capacitados para executar as atividades do Programa Saúde na Escola, embora apenas 30,5\% tenham participado de capacitações. Há associação estatística entre experiência e capacitação profissional. Conclusão: Os profissionais que executam as atividades do Programa Saúde na Escola são submetidos a poucos processos de capacitação, embora se sintam aptos para executar as atividades propostas.

\section{DESCRITORES}

Serviços de Saúde Escolar; Atenção Primária à Saúde; Enfermagem de Atenção Primária; Capacitação Profissional.

\section{RESUMEN}

Objetivo: Analizar la asociación entre experiencia y capacitación profesional en la ejecución del Programa Salud en la Escuela. Método: Estudio descriptivo, inferencial, cuantitativo y normativo. Los datos fueron recogidos en el período de mayo a julio de 2017 mediante cuestionario construido a partir de las normalizaciones del Programa Salud en la Escuela, con la participación de profesionales de la Estrategia Salud de la Familia. Resultados: Participaron en el estudio 105 profesionales. El promedio de experiencia profesional en la Estrategia Salud de la Familia y en el Programa Salud en la Escuela es de 12,1 y 7,2 años, respectivamente. Se identificó que el 94,3\% de los profesionales se sienten capacitados para llevar a cabo las actividades del Programa Salud en la Escuela, aunque solo el 30,5\% hayan participado en capacitaciones. Existe asociación estadística entre experiencia y capacitación profesional. Conclusión: Los profesionales que llevan a cabo las actividades del Programa Salud en la Escuela se someten a pocos procesos de capacitación, aunque se sientan aptos para llevar a cabo las actividades propuestas.

\section{DESCRIPTORES}

Servicios de Salud Escolar; Atención Primaria de Salud; Enfermería de Atención Primaria; Capacitación Profesional.

\section{REFERENCES}

1. Batista MSA, Mondini L, Jaime PC. Actions of the School Health Program and school meals in the prevention of childhood overweight: experience in the municipality of Itapevi, São Paulo State, Brazil, 2014. Epidemiol Serv Saúde [Internet]. 2017 [cited 2017 Dec 6];26(3):56978. Available from: http://www.scielo.br/scielo.php?pid=S2237-96222017000300569\&script=sci_arttext\&tlng=en

2. Cord D, Gesser M, Nunes ASB, Storti MMT. As significações de profissionais que atuam no programa saúde na escola (PSE) acerca das dificuldades de aprendizagem: patologização e medicalização do fracasso escolar. Psicol Ciênc Prof [Internet]. 2015 [citado 2017 dez. 6]35(1);40-53. Disponível em: http://www.scielo.br/pdf/pcp/v35n1/1414-9893-pcp-35-01-00040.pdf

3. Machado MFAS, Gubert FA, Meyer APGFV, Sampaio YPCC, Dias MSA, Almeida AMB, et al. The Health School Programme: a health promotion strategy in primary care in Brazil. Rev Bras Crescimento Desenvolv Hum [Internet]. 2015 [cited 2017 Dec 6];25(3):307-12. Available from: http://www.revistas.usp.br/jhgd/article/view/96709

4. Ferreira IRC, Moysés SJ, França BHS, Carvalho ML, Moysés ST. Percepções de gestores locais sobre a intersetorialidade no Programa Saúde na Escola. Rev Bras Educ [Internet]. 2014 [citado 2017 dez. 6];19(56):61-76. Disponível em: http://www.scielo.br/pdf/rbedu/v19n56/v19n56a04.pdf

5. Silva MAI, Silva JL, Pereira BO, Oliveira WA, Medeiros M. The view of teachers on bullying and implications for nursing. Rev Esc Enferm USP [Internet]. 2014 [cited 2017 Dec 6];48(4):723-30. Available from: http://dx.doi.org/10.1590/S0080-623420140000400021

6. Brasil EGM, Silva RM, Silva MRF, Rodrigues DP, Queiroz MVO. Adolescent health promotion and the School Health Program: complexity in the articulation of health and education. Rev Esc Enferm USP. 2017;51:e03276. DOI: http://dx.doi.org/10.1590/s1980-220x2016039303276

7. Farias DN, Ribeiro KSQS, Anjos UU, Brito GEG. Interdisciplinaridade e interprofissionalidade na Estratégia Saúde da Família. Trab Educ Saúde [Internet]. 2018 [citado 2018 fev. 27];16(1):141-62. 2018. Disponível em: http://www.scielo.br/pdf/tes/v16n1/1678-1007-tes-19817746-sol00098.pdf

8. Contandriopoulos AP. Avaliando a institucionalização da avaliação. Ciên Saúde Coletiva [Internet]. 2006 [citado 2017 dez. 6];11(3):70511. Disponível em: http://www.scielo.br/pdf/csc/v11n3/30984.pdf

9. Falkenberg MB, Mendes TPL, Moraes EP, Souza EM. Educação em saúde e educação na saúde: conceitos e implicações para a saúde coletiva. Ciên Saúde Coletiva [Internet]. 2014 [citado 2017 dez. 6];19(3):847-52. Disponível em: http://www.scielo.br/pdf/csc/v19n3/14138123-csc-19-03-00847.pdf

10. Fermino V, Amestoy SC, Santos BP, Casarin ST. Family Health Strategy: nursing care management. Rev Eletr Enf [Internet]. 2017 [cited 2017 Dec 6];19(a05):1-10. Available from: https://revistas.ufg.br/fen/article/view/42691/22859

11. Farias ICV, Sá RMPF, Figueiredo N, Menezes Filho A. Análise da intersetorialidade no Programa Saúde na Escola. Rev Bras Educ Med [Internet]. 2016 [citado 2017 dez. 6];40(2):261-7. Disponível em: http://www.scielo.br/pdf/rbem/v40n2/1981-5271-rbem-40-2-0261.pd 
12. Navarro ASS, Guimarães RLS, Garanhani ML. Trabalho em equipe: o significado atribuído por profissionais da Estratégia de Saúde da Família. REME Rev Min Enferm [Internet]. 2013 [citado 2017 dez. 6];17(1):70-6. Disponível em: http://www.reme.org.br/artigo/detalhes/579

13. Lima EFA, Sousa AI, Leite FMC, Lima RCD, Souza MHN, Primo CC. Evaluation of the Family Healthcare Strategy from the perspective of health professionals. Esc Anna Nery Rev Enferm [Internet]. 2016 [cited 2017 Dec 6];20(2):275-80. Available from: http://www.scielo.br/ pdf/ean/v20n2/en_1414-8145-ean-20-02-0275.pdf

14. Segrott J, Holliday J, Murphy S, Macdonald S, Roberts J, Moore L, et al. Implementation of a Cooking Bus intervention to support cooking in schools in Wales, UK. Health Educ (Lond). 2017;117(3)3:234-51. DOI: https://doi.org/10.1108/HE-06-2014-0073

15. Orava T, Manske S, Hanning R. Support for healthy eating at schools according to the comprehensive school health framework: evaluation during the early years of the Ontario School Food and Beverage Policy implementation. Health Promot Chronic Dis Prev Can. 201;37(9):303-12. DOI: http://dx.doi.org/10.24095/hpcdp.37.9.05

16. Sousa MC, Esperidião MA, Medina MG. Intersectorality in the 'Health in Schools' Program: an evaluation of the political-management process and working practices. Ciên Saúde Coletiva [Internet]. 2017 [cited 2018 Feb 27];22(6):1781-90. Available from: http://www.scielo. br/pdf/csc/v22n6/en_1413-8123-csc-22-06-1781.pdf 